УДК 2-675:[27:124.4]

DOI 10.35423/2078-8142.2020.1.10

А. О. Кислий, кандидат філософських наук, дочент, докторант кафедри богослов'я та релігієзнавства, Національний педагогічний університет ім. М. П. Драгоманова м. Київ, Україна e-mail: a.kysliy@ukr.net ORCID: https://orcid.org/0000-0001-8988-8242

\title{
СУЧАСНИЙ ЕКУМЕНІЗМ ТА ФОРМУВАННЯ ХРИСТИЯНСЬКОГО СОЦІАЛЬНОГО ІДЕАЛУ
}

У статі визначено актуальність та тендениії вивчення проблем сучасного екуменізму. Інтерес до иього питання викликаний соціальними та духовними інтенціями нинішнього світу та необхідністю переосмислення нової соиіальної реальності в контексті напрацювання теоретичних ідей досконалого суспільного устрою. 3'ясовано, щзо основою всієї історії екуменізму як християнського руху, спрямованого на об'єднання иерков, є пошук плодоносних шляхів формування християнської єдності у сфері соиіальних питань. Взаємозв'язки і діалог між новими та традиційними християнськими церквами та організаціями є важливими для сталого розвитку соціальної домінанти. Багатовікова історія християнських універсальних иінностей визнається важливим аргументом у конструюванні аксіологічних пріоритетів формування ідеалів сучасного і майбутнього суспільства. Реальна дієвість і результативність екуменізму в соиіальній площині бачиться у збереженні власної релігійної самобутності та переосмисленні ставлення до суспільного життя, зміџнення пріоритетів соціального служіння. Досвід боротьби за унеможливлення соціальних негараздів та визначення напрямів формування позитивних стійких духовно-морально координат сочіальних змін засвідчує перспективність формування спільних основ християнського сочіального ідеалу. 
Ключові слова: ідеал, соиіальний ідеал, християнські ичінності, екуменізм, екуменічний рух, міжхристиянські відносини, міжрелігійний діалог.

Для сучасного релігієзнавства і богослов'я актуальним, дискусійним та необхіднім є обгрунтування теоретичних орієнтирів та практичних шляхів розвитку суспільства. В умовах соціальних i духовних зрушень сучасного світу їх невід'ємною складовою $є$ поглиблення інтересу до екуменізму як сучасного християнського руху, що спрямований на оновлення й об'єднання церков. Його зародженню на перетині XIX-XX століть у межах ліберального протестантизму і втягненню у свою сферу православної і римокатолицької церкви спонукала вимога виявлення християнської єдності й узгодженої дії проти секулярних, раціоналістичних і матеріалістичних тенденцій, соціальних негараздів тощо. Тривала боротьба світської і духовної влади на Заході призвела до їх розмежування і вирізнення християнської релігії у відокремлену від громадської, приватну сферу. При цьому зорієнтованість християнства на соціальну активність і на відносну цінність мирської діяльності, за певних умов, сприяла формуванню ціннісних орієнтирів сучасної соціальної сфери.

Сучасний екуменічний рух формується під впливом плюралізму та досвіду налагодження спільного, важливого, але суперечливого діалогу, взаємодій та запозичень різних культур, ідей та ідеологій у межах християнського вчення. Враховуючи закономірності розвитку релігії, деякі релігієзнавці розглядають екуменізм як найвищу фазу іiі розвитку, що полягає у злитті різних віросповідань, як духовний рух, який стимулюватиме лише цей окремий сегмент християнства в нових соціально-культурних умовах.

Основною лінією, що пронизує всю історію сучасного екуменізму, є суспільна сфера інтересів, співвідношення Церкви і суспільства, ролі Церкви в суспільстві, боротьба за справедливість і мир тощо. Вона підкреслює важливість прагнення християнства до взаєморозуміння і діалогу для сталого розвитку соціальної домінанти і є свідченням тисячолітньої історії створення таких цінностей та ідеалів, що безперечно будуть конструктивними у формуванні сучасного і майбутнього суспільства. Нові та традиційні релігійні 
організації і церкви рівною мірою постали перед викликами плюралізму, приватизації інтересів і зрівнялись у можливості визначитися 3 пріоритетами ціннісної сфери суспільства. 3 усього кола аксіологічних питань принципово важливе значення має пошук спільних основоположних засад суспільного ідеалу.

Отже, метою роботи є релігієзнавче дослідження сучасного екуменізму як пошук християнськими мислителями спільних ціннісних основ формування соціального ідеалу.

Сьогодні християнський екуменізм є емпіричним фактом i втілюється в особистих і групових ініціативах своїх прихильників та реалізується через різні інститути. Водночас, не зважаючи на тривалу історію суттєвих зусиль багатьох церковних діячів і релігійних мислителів, має значні труднощі, неприйняття і нерозуміння серед людей та різних організацій. Цьому складному процесу приділяється значна увага з боку як богословської, так і світської літератури. Помітне місце в осмисленні аксіологічного змісту екуменізму займають праці християнських релігійних філософів, таких як: М. Бердяєв, С. Булгаков, В. Зеньковський, І. Ільїн, М. Лоський, П. Новгородцев, В. Соловйов, $\quad$. Трубецькой, П. Флоренський, Г. Флоровський, С. Франк та ін. На Заході висвітлення феномена діалогу релігій присвячені праці К. Барта, М. Бубера, Г. Марселя, Ф. Ебнера, Ф. Розенцвейга, О. Розеншток-Хюссі, К. Ранера, Ю. Мольтмана, Х. Кокса, Г. Кюнга та ін. Широке поле дослідницької проблеми потребує звернення до офіційних церковних документів та праць представників християнської теології, насамперед патріархів Варфоломія I (Архондоніса) та Кирила (Гундяєва); митрополитів Іларіона (Алфеєва), Володимира (Сабодана), Дамаскіна (Папандреу), Йоана (Зізіуласа), Каліста (Уера), Філарета (Вахромеєва); диакона А. Кураєва та ін., а також католицьких та протестантських ієрархів i теологів, які зробили значний внесок у розробку філософськотеологічних основ екуменічного діалогу як край важливої загальнохристиянської компоненти: пап Павла VI, Івана Павла II, Бенедикта XVI, кардиналів Й. Віллебрандса, В. Каспера, Е. Кассіді, К. Коха; протестантських теологів Ф. Поттера, К. Райзера, В. Темпла та ін.

Осмисленню екуменізму в контексті аналізу особливостей розвитку суспільства на основі християнських цінностей присвячено праці вітчизняних релігієзнавців, філософів, культурологів, 
соціологів, істориків: В. Андрущенка, М. Бабія, І. Богачевської, В. Бондаренка, В. Сленського, С. Здіорука, Н. Іщук, О. Кисельова, А. Колодного, Ю. Корнійчук， Н. Кочан， В. Кременя， В. Любащенко, М. Мариновича, О. Недавньої, Г. Пирог, М. Поповича, О. Сагана, В. Табачковського, В. Титаренко, Л. Филипович, Л. Чорної, Ю. Чорноморця, В. Шинкарука, П. Яроцького та ін.

У богословському та релігієзнавчому середовищі існують суттєві розходження в самому розумінні екуменізму. Із християнської точки зору екуменізм за своїм змістом означає рух за зближення і поєднання різних релігійних традицій. Але розуміння сенсу, кінцевої мети і засобів екуменічної діяльності вельми різняться. Сучасний православний богослов і публіцист А. Кураєв у книзі «Виклик екуменізму» дає десять понять екуменізму. Серед основних: співробітництво християнських конфесій у проповіді Свангелія і в боротьбі з язичництвом; подолання деяких стереотипних негативних уявлень один про одного; спосіб ознайомлення неправославного світу з православ'ям і запозичення православ'ям позитивного досвіду з неправославного світу; терпимість до людини інших переконань; відрізняти другорядне від головного тощо. Частина 3 них отримала позитивну оцінку Православної церкви, окремі $з$ них вона вважає дискусійними, а деякі, наприклад, благодатна рівність всіх християнських церков, - неприйнятними. Одним 3 важливих і привабливих сенсів екуменічного діалогу, що $є$ безперечним для всіх християн, А. Кураєв вважає співпрацю в царині вирішення важливих та звичайних життєвих людських та суспільних проблем [8].

Видатний діяч екуменічного руху, професор порівняльної історії релігії і теології Марбургського і Мюнхенського університетів Ф. Гайлер у своїх дослідженнях намагається відшукати таке поле досвіду релігійного життя, де виявляється духовна єдність людства. Незважаючи на свою прихильність до католицизму, він цікавиться не лише християнством, а й східними релігіями та доводить необхідність релігійно-практичної мотивації не тільки діалогу, але й об'єднання всіх релігій в єдину всесвітню церкву. Релігії можна побачити як одне ціле, використовуючи феноменологічний метод, рухаючись шляхом, що утворює безперервні лінії дотику. Такий процес відбувається в межах трьох концентричних кіл, 124

H.Skovoroda Institute of Philosophy of the NAS of Ukraine 
що являють собою три суб'єктивні світи: світ зовнішніх проявів релігії, тобто інституційний елемент релігії. Він розділений на три частини: священні об'єкти (сакральні простір і час, священні числа, священні дії і т.д.); священні слова (священні тексти, слово Боже, ім'я Бога, міфи, пророцтва, доктрини, молитви, звернення до Бога і т.д.); святі і священне співтовариство. Другий - це світ духовних уявлень, тобто мислимий, оповідний елемент релігії. Світ духовних уявлень, пов'язаних з невидимим Богом і його видимими справами. Третій - це світ психічного досвіду, тобто містичний елемент релігії. У його основі перебуває об'єкт релігії - божество, божественна реальність, що сприймається тільки через зовнішні прояви - пов'язаний з індивідуальним досвідом, що відкривається людині у вигляді благодаті, істини, порятунку, любові, ідеалу Бога невідомого - абсолюту. Світ досвіду відображає особисте ставлення людини до священного об'єкта і пов'язаний зі світом найвищих цінностей [11, с. 171].

Отець Лео Лефебюр, професор богослов'я Джорджтаунського університету у Вашингтоні (США), фахівець з порівняльних досліджень різних релігій та питань міжрелігійних відносин пов'язує екуменізм 3 найбільш активними суб'єктами міжхристиянського діалогу. Але він переконаний, що в сучасних умовах пошук взаєморозуміння не повинен відбуватися тільки всередині однієї релігії (міжхристиянський чи міжцерковний діалог). Головною для нього є ідея світового екуменізму, до якого повинні долучатися не лише спеціально створені церковні інституції, а й інші мирянські об'єднання, які не обмежуються християнським віросповіданням. Найбільш необхідним і перспективним він вважає діалог між християнами і мусульманами як на міжнародному, так і на локальному рівнях. Але розв'язання важливих соціальних питань та вироблення сучасних ідей соціального блага буде можливим за умов широкого залучення до участі в діалозі основних релігій (християнство, іудаїзм, буддизм, іслам, індуїзм та ін.) та їх лідерів або уповноважених осіб.

Саме поняття «релігія», доводить канадський теолог Уілфред Кантуелл Сміт, - це західноєвропейська ідея, і неможливо ініціювати діалог між всіма так званими релігіями. На доктринальному та інших рівнях діалог можливий і потрібний лише в межах христи- 
янства. Християнство - це історико-культурний контекст взаємин людини з Богом і його істина пов'язана саме 3 вірою індивіда, а ритуали, мораль тощо важливі не самі по собі, а лише у зв'язку 3 вірою. Тому і діалог між конфесіями розуміється як процес проникнення «від віри до віри» і взаєморозуміння через поглиблення i взаємозбагачення особистої віри [11, с. 172-173].

Екуменічний рух як об'єктивно нове явище у XX ст., що розпочався з регулярних з'їздів і конференцій серед протестантських спільнот, охопив широкі кола християн усього світу. Для багатьох церков, в тому числі православної, це був новий виклик, адже він поставив питання церковної повноти. Відзначимо, що результативні зустрічі у самому православному середовищі з пастирських та богослужбових питань загальноцерковного рівня почались лише у другій половині XX ст. До сьогодні для православ'я помітною проблемою є адаптація складних богословських творів та термінів, що складалися та повідомлялися грецькою мовою, до розуміння й прийняття всіма віруючими християнами з умовою збереження їх істинності.

Результатом спільних зустрічей у Женеві, Лозані, Стокгольмі стало утворення Всесвітньої Ради Церков, установча асамблея якої відбулася у 1948 р. в Амстердамі за участі представників 147 церков і християнських релігійних організацій. На іiі засіданнях Православна церква ніколи і ні в чому не відступала від своїх переконань у питаннях віри, догматичного вчення і вірності Христу i Євангелію. Йти на компроміси і поступки справді доводилося лише в політичних і суспільних питаннях [2, с. 44], визнаючи важливим аспектом участі в екуменічному русі солідарність у служінні потребам стражденних, обтяжених і пригноблених; у спільному захисті прав людини, справедливості, миру, екології у сприянні економічному і соціальному добробуту країн; допомоги біженцям, мігрантам і переслідуваним етнічних груп і національних меншин тощо [2, с. 47].

Православна Церква розглядає екуменізм крізь призму власної еклезіології, тобто об'єднання християнства навколо себе як єдиної, святої, соборної й апостольської Церкви. А будь-які нові пропозиції у соціальній сфері викликають занепокоєння й позначаються як такі, які підривають основи християнської віри, хрис126 
тиянського життя людини і суспільства, що залишається дисонансом для католиків та протестантів. Така ортодоксальність та «природний» консерватизм Православної церкви, на думку А. Шишкова, може призвести до того, що екуменічний рух ризикує зазнати поразки у боротьбі за православ'я [12].

Серед провідних православних богословів та мирян $є$ такі, які негативно сприймають не лише екуменічний рух, а й міжправославний діалог, намагаються продемонструвати свою пріоритетність у цьому процесі. Святий і Великий Собор Православної Церкви, що відбувся у червні 2016 р. на Криті, зібрав 10 з 14 Помісних Православних Церков світу 3 приводу відповідального ставлення до сучасних проблем суспільства. Суперечки у процесі попередньої підготовки документів, першою чергою з питання автономії та способу іiі проголошення, стали причиною відсутності Російської Православної Церкви на Соборі. Водночас, за ініціативи Патріарха Московського і всієї Русі Кирила, підготовлено і проведено Всесвітній Російський Народний Собор: «Росія і Захід: діалог народів у пошуках відповідей на цивілізаційні виклики». Його ключовими меседжами були судження з приводу того, що сучасне західне християнство, і саме суспільство, що сформувалось на його основі, зрікається своїх традиційних цінностей. Західна цивілізація, експортуючи секулярний світогляд, може ослабити внутрішнє духовне ядро інших цивілізацій і навіть можливість їх подальшого самобутнього існування. I тому Російська Православна Церква закликає всі християнські громади, послідовників інших релігій, представників світської культури об'єднатися навколо спільної системи цінностей для протидії наступу «секуляристської антицивілізації». Перспективним бачиться не екуменічний, а над-екуменічний проект, що виходить за межі міжхристиянського і міжрелігійного діалогу та базується на основі міжнародної системи правових і моральних координат, що включають спільні цінності, притаманні світовим релігіям та культурам [4].

Не зважаючи на складність та суперечливість багаторічного досвіду міжконфесійного діалогу, Православна церква заявляє про щирість своїх прагнень єдності з усіма християнами заради любові та бажання ділитися духовними багатствами своєї традиції. Діалог 3 християнами інших спільнот дає можливість побачити багато 
спільних інтересів і подібностей, що говорить про спільне коріння і багатокультурні прояви християнства. Охоплюючи все людське життя, діалог, відбуваючись в особистій, соціальній або політичній площині, спонукає кожного замислитися над унікальними цінностями своєї віри, церкви, традиції, культури, богослов'я тощо. Повернення до еклезійних проблем, побудованих на основі євхаристичної єдності і цілісності, є засадничими для сучасного й майбутнього Церкви. Онтологія діалогу всього християнства вбачається ціннісно-важливою основою формування соціального ідеалу [6].

Католицька церква активно включилася в екуменічний діалог після Другого Ватиканського Собору. На Соборі вона здійснила успішні спроби по-новому відкрити для себе християн інших конфесій, запросивши як спостерігачів протестантських та православних представників, можливо чи не вперше назвавши їх у документах церквами і церковними спільнотами. Тема екуменічного діалогу перетворюється на перший пункт порядку денного життя Церкви, адже він стосується всіх справ і починань, які виникають залежно від різних потреб Церкви і можливостей, наданих даною епохою, і прагне сприяти християнській єдності [5].

Розвиток екуменічного діалогу Католицької церкви значною мірою відбувається завдяки діяльності папи Івана-Павла II. Підтвердженням цього є його зустрічі на найвищому рівні $з$ предстоятелями різних релігійних організацій та авторство численних богословських праць і документів на тему об'єднання християн, серед яких Апостольський лист про Східні Церкви «Orientale Lumen» (Світло Сходу) та енцикліка «Ut unum sint» (Щоб усі було одно) [10]. Адресуючи свої звернення, першою чергою, до православної церкви-сестри, він намагається довести всьому світу важливість справи об'єднання всіх християн. Енцикліка говорить про нове відкриття шляху братнього і сестринського спілкування між християнами як про велике досягнення екуменічного діалогу. У ньому не повинно бути торгів та загравань, що мають місце між компаніями і профспілками 3 метою вилучення 3 переговорного процесу якнайбільше користі. Останнім часом, на думку Вальтера Каспера, термін «церкви-сестри» ризикує в певному сенсі знецінитися в деяких колах, адже інколи використовується і по відношенню до протестантських церковних спільнот. Виходячи 3 цього, Католиць128

H.Skovoroda Institute of Philosophy of the NAS of Ukraine 
ку церкву найбільше хвилює можливість досягнення єдності Церкви в результаті екуменічного зближення між Сходом і Заходом [7, с. 120].

У книзі «Християнське возз'єднання. Екуменічна проблема в православній свідомості», що була видана Християнським союзом молодих людей у Парижі, М. Бердяєв застерігав про небезпеки розуміння вселенськості християнства занадто поверхово. Він наголошував на великому значенні соціального питання, що є центральним для християнської свідомості та для об'єднання християнського світу. Від ставлення християнства всіх віросповідань до соціального життя залежить доля християнства у світі. Більше того, саме у соціальній площині християнство повинне об'єднатися для протидії антихристиянським силам. Сучасна епоха нерідко схиляється до розуміння християнства як релігії соціальної і моральної. Але важливо, що «християнство не $є$ соціальна релігія, і основи християнства не соціальні і не моральні, а містичні і духовні» [1, с. 115-116].

Усі християни одночасно і в особистому, і церковному житті спільні в живому спілкуванні із Христом. Єдність християнського життя забезпечується особистим досвідом любові до Господа, а не догматами і догматичними відмінностями. Не у догматичній свідомості, а у духовному житті, у містичному дотику до божественної реальності відбувається єднання християн. Живе спілкування пов'язує і зобов'язує представників різних віросповідань, створюючи можливість такого взаємного пізнання, яке діє більш переконливо, ніж слова, відображені у формулах і постановах, закріплені у звітах і рішеннях. I чим більші зусилля духовного життя, тим природніше воно переливається за віросповідні межі і з'єднує людей. Власне без такого спорідненого досвіду не може бути й християнського єднання при всій його множинності. Тому екуменічна свідомість повинна відшукати не догматичні та віросповідні розбіжності, а загальні християнські надбання. Свідоме культивування взаємного спілкування мирян, священства, представників богословської думки, обмін світськими та богословськими ідеями, результатами наукових досліджень робить поділ християнських віросповідань певною мірою умовним. Але до цього часу проблемним залишається однобічність історичного досвіду християн різних ві- 
росповідань гостро реагувати на догматичні розбіжності, накладаючи анафеми та звинувачуючи в єресі [3, с. 101-103].

Природне споконвічне покликання Церкви поширювати свій вплив у всіх місцях і служити в несенні свідоцтва людині, суспільству і світу заради їхнього порятунку веде ії до необхідності окреслення і вирішення недугів суспільства як проблем першої необхідності для самих християнських церков. Суспільні хвороби, породжені секуляризацією, раціоналістичними і матеріалістичними тенденціями і теоріями, організованим атеїзмом, насильством, розбещеністю, расизмом, війнами, пригніченням мас, соціальною нерівністю, голодом мільйонів людей, хаосом біженців, еміграцією, падінням моралі підкреслюють очікування змін у майбутньому. Нові й постійно зростаючі реалії кличуть і вимагають розширення масштабів діяльності церков, де дедалі більше відчувається жива необхідність почути голос церков, які несуть відповідальність за життя людини [13].

Об’єктивний і ефективний форум для зустрічі і діалогу всіх церков і всіх християн в їх зусиллях зі зближення і досягнення єдності одночасно суттєво активізував їх співпрацю у справі служіння миру в усьому світі, соціальної справедливості і братерства, що $\epsilon$ основними цілями екуменічного руху. Питання формування християнського соціального ідеалу досить тісно пов'язується з боротьбою та унеможливленням соціальних негараздів, зміцненням міжнародного співробітництва всіх людей і народів незалежно від їх релігійних, ідеологічних, політичних переконань чи приналежності. Органічне поєднання із завданням пошуку найбільш ефективних шляхів для формування християнської єдності в сфері соціальних питань буде належним міжхристиянським форумом єдності у вірі, що дає можливість уникнути однобічності екуменізму. Екуменічні діалоги різними способами стали підтвердженням правомочності цієї ідеї. Зв'язок з церквами і церковними спільнотами існує не лише в теорії, а і в реальності, що розкривається на практиці, адже досвід засвідчує, що «об'єднує нас набагато більше, ніж того, що все ще, на жаль, нас розділяє» [7, с. 73].

Реальна дієвість та результативність екуменічного руху підтверджується виходом за межі міжхристиянської полеміки й дискуciï. Сучасний і майбутній екуменічний діалог важливий у позабо130

H.Skovoroda Institute of Philosophy of the NAS of Ukraine 
гословському середовищі на рівні вирішення соціальних питань. Він повинен вестися партнерами не заради формальних досягнень, а можливого і необхідного компромісу у питаннях перспективного взаємного співіснування і співробітництва, побудованого на основі толерантності, терпимості, щирості, любові і поваги до всіх людей тощо. Діалог послідовників різних віросповідань в умовах спільної соціально активної діяльності неминучий і веде до безконфліктного співіснування в єдиному суспільному просторі. Взаєморозуміння і спільність, навіть об'єднання в різноманітних сферах для вирішення соціальних проблем забезпечує зближення окремих християн та поглиблює комунікацію християнських організацій та церков.

Важливими та перспективними результатами екуменізму $є$ збереження своєї релігійної самобутності та установлення напрямів позитивних соціальних змін на основі спільних універсальних християнських цінностей та ідеалів. Любов, свобода, мир, милосердя, справедливість, засудження гріхів притаманні всім конфесіям і конструктивно допомагають зорієнтуватись людині в цінностях особистого і суспільного життя. Першою чергою це стосується формування стійких морально-етичних координат світової системи правових, політичних, економічних відносин. Нова соціальна комунікація веде до посилення тих стійких елементів християнського соціального ідеалу, який можливий на даний час і на перспективу й, водночас, його переосмислення і адаптація до нової соціальної реальності, яка характеризується відкритістю і хаотичністю сучасного розвитку.

Нинішній соціальний вимір екуменізму вийшов за свої власне релігійні межі й дає можливість стверджувати, що жорстке розділення між християнськими церквами стає не лише непродуктивним, а й абсолютно шкідливим як для християнства, так і для всього людства. Відображаючи динамічні інтенції суспільних викликів сучасності, він дедалі більше розуміється як певний імператив, що вимагає концептуальної розробки ціннісних основ формування соціального ідеалу та інституційного оформлення його соціального рівня. Сьогодні і в подальшому церкви дедалі більше шукатимуть шляхи порозуміння не в доктринальній, а у суспільній сфері екуменічних відносин. Вони стосуються досить широкого кола пи- 
тань, що викликають тривогу людей і спільнот незалежно від їх конфесійної приналежності [9].

На доручення Вселенського Патріарха Варфоломія спеціальна комісія священнослужителів та богословів, фахівців і вчених, а також соціальних працівників і громадських лідерів підготувала офіційний документ із соціального вчення Православної Церкви, який було розглянуто та затверджено Святим і Священним Синодом Константинопольської Церкви на початку 2020 р. Планується, що він служитиме «твердою основою для посилань і обговорення життєво важливих питань та викликів, що стоять нині перед світом», «надати критерії та орієнтири соціальної відповідальності Православної Церкви перед викликами та перспективами сучасного світу, не нехтуючи при цьому позитивним потенціалом та перспективами сучасної цивілізації». Першочерговими реальними соціальними домінантами визначається громадянський лад, свобода, права людини й демократія. Але, як зазначається в документі, православні християни «не повинні ставитися до цих цінностей як до чогось належного, а навпаки, активно підтримувати їх і працювати задля збереження й розширення демократичних інституцій і звичаїв у правових, культурних і економічних рамках своїх суспільств». «Насправді ж Церква зацікавлена в тому, щоб інституційний зв'язок християнства з інтересами держави був якомога слабшим, не тому, що Церква прагне зовсім залишити суспільну сферу, а тому, що вона покликана сповіщати Свангеліє всьому світу й у всьому служити Богу, не компрометуючи себе допасуванням до чиїхось мирських амбіцій» [6].

Для всіх християн принциповими залишається визнання Ісуса Христа як Бога і Спасителя та бажання служити, спільно шукаючи вираження цієї єдності в роботі і житті. «Екуменічна духовність формується на біблійної основі, з цієї причини не може бути однобокою і спрямованою тільки всередину або ж виключно еклезіоцентричною. Так як екуменізм не може бути замкнутим на самому собі рухом, екуменічна духовність теж повинна бути спрямована назовні своїх меж» [7, с. 237]. Такі висновки кардинала Вальтера Каспера, голови Папської Ради для сприяння єдності між християнами, будуть важливими для всіх екуменічних поступів християн у соціальній площині. 
Отже, принциповий інтерес сучасного екуменізму спрямований на пошук шляхів формування органічної християнської єдності у сфері соціальних питань. Жорстка полеміка між християнськими церквами бачиться неефективною для вирішення соціально важливих і духовних проблем нинішнього світу. Дієвість та результативність екуменізму в соціальній площині підтверджується готовністю нових та традиційних християнських релігійних організацій до взаєморозуміння і діалогу для сталого розвитку соціальної царини. Формування ідей ідеального суспільного устрою на основі християнських цінностей та істин $є$ суттєвим аргументом у конструюванні аксіологічних пріоритетів сучасного і майбутнього суспільства. Воно залежить від того, наскільки певні аспекти суспільного життя визнаються безперечними, а окремі з них потребують удосконалення. Збереження християнськими церквами і богословами власної релігійної самобутності та переосмислення відношення до нинішніх пріоритетів суспільного життя 3 метою формування позитивних стійких духовно-моральних координат соціальних змін веде до визрівання спільних стійких основ християнського соціального ідеалу.

\section{ЛITEPATУРA}

1. Бердяев Н. Вселенскость и конфесиоанлизм. Православие и экуменизм. Документы и материаль 1902-1998. Москва, 1999. С. 109118.

2. Боровой В., Буевский А. Русская Православная Церковь и экуменическое движение (историко-богословское обозрение). Православие $и$ экуменизм. Документы и материаль 1902-1998. Москва, 1999. С. 8-48.

3. Булгаков С. У Кладезя Иаковля (Ин. 4, 23). О реальном единстве разделенной церкви в вере, молитве и таинствах. Православие и экуменизм. Документы и материаль 1902-1998. Москва, 1999. С. 96-108.

4. Глобальные вызовы. Религия и секуляризм в современном мире. Всемирный русский народный собор. 06.07.2016. URL: https://vrns.ru/news/4178

5. Декрет об экуменизме. Документы II Ватиканского Собора. Москва : Паолине, 2004. С. 170-191.

6. За життя світу. На шляху до сочіального етосу Православної Церкви. URL: https://risu.org.ua/ua/index/resourses/church_doc/ecumenical_ 
patri-

?chate_doc/79457/?utm_source=gravitec\&utm_medium=push\&utm_campaign

7. Каспер В. Да будет все едино. Призыв к единству сегодня / пер. с англ. Москва : ББИ, 2008. 301 с.

8. Кураев А. Вызов экуменизма / изд. 2-е, испр. и доп. Москва : Издательский Совет РПЦ, 2003. 384 с.

9. Місія Православної Церкви в сучасному світі. URL: http://kyivpravosl.info/dokumenty-vsepravoslavnoho-soboru/misiay

10. Энциклика Иоанна Павла II об экуменическом служении Ut unum sint («Да будут все едино»). URL: http://www.katolik.ru/dokumentyvatikana/item/3575-entsiklika-ioanna-pavla-ii-ob-ekumenicheskom-sluzheniiut-unum-sint-da-budut-vse-edino.html

11. Шахнович М. Феноменологическое религиоведение и проблема межрелигиозного диалога. Онтология диалога: метафизический и религиозный опыт. Филос.-культурол. исслед. центр «Эйдос». Глав. ред. Л. Морева. Санкт-Петербург, 2002. С. 169-174.

12. Шишков А. Два экуменизма: консервативные христианские альянсы как новая форма экуменического взаимодействия. Государство, религия, цеерковь в России и за рубежом. 2017. № 1. С. 269-300.

13. Экуменическое движение. Антология ключевых текстов / сост. М. Киннемон, Б. Коун. Москва : ББИ, 2002. 615 с.

\section{REFERENCES}

Berdyaev, N. (1999). Universality and Confessionalism. Orthodoxy and Ecumenism. Documents and Materials. 1902-1998. Moscow. P. 109-118. [In Russian].

Borovoy, V., Buevsky, A. (1999). Russian Orthodox Church and the Ecumenical Movement (historical and theological review). Orthodoxy and Ecumenism. Documents and Materials. 1902-1998. Moscow. P. 8-48. [In Russian].

Bulgakov, S. (1999). By Jacob's Well (John IV, 23). On the Actual Unity of the Divided Church in Faith, Prayer and Sacraments. Orthodoxy and Ecumenism. Documents and Materials. 1902-1998. Moscow. P. 96-108. [In Russian].

Global challenges. (2016). Religion and Secularism in the Modern World. World Russian People's Council, 06.07. Retrieved from https://vrns.ru/news/4178. [In Russian].

Unitatis Redintegratio (2004.). Documents of the Second Vatican Council. Moscow: Paoline. P. 170-191. [In Russian]. 
For the Life of the World: Towards a social ethos of the Orthodox Church. Retrieved from

https://risu.org.ua/ua/index/resourses/church_doc/ecumenical_patrirchate_doc/7 9457/?utm_source=gravitec\&utm_medium=push\&utm_campaign. [In Ukrainian].

Kasper, W. (2008.) That They May All Be One. The Call to Unity. Moscow: St. Andrew's Biblical Theological Institute. 301 p. [In Russian].

Kuraev, A. (2003.) The Challenge of Ecumenism. Moscow: Publishing Council of the Russian Orthodox Church. 384 p. [In Russian].

The Mission of the Orthodox Church in Today's World. Retrieved from http://kyiv-pravosl.info/dokumenty-vsepravoslavnoho-soboru/misiay. [In Ukrainian].

Encyclical of John Paul II on the Ecumenical Ministry «Ut unum sint». Retrieved from http://www.katolik.ru/dokumenty-vatikana/item/3575-entsiklikaioanna-pavla-ii-ob-ekumenicheskom-sluzhenii-ut-unum-sint-da-budut-vseedino.html. [In Russian].

Shakhnovich, M. (2002). Phenomological Religious Studies and the Problem of Interreligious Dialogue. Ontology of Dialogue: Metaphisical and Religious Experience. The Philosophical and Cultural Research Centre «EIDOS». Editorin-chief: Liubava Moreva. St. Petersburg. P. 169-174. [In Russian].

Shishkov, A. (2017). Two Ecumenisms: Conservative Christian Alliances as a New Form of Ecumenical Cooperation. State, Religion and Church in Russia and Worldwide, 1, 269-300. [In Russian].

The Ecumenical Movement: An Anthology of Key Texts and Voices. (2002). Michael Kinnamon, Brian E. Cope (Comp.). Moscow: St. Andrew's Biblical Theological Institute. 615 p. [In Russian].

\section{Anatoliy Kysliy}

Candidate of Philosophical Sciences (Ph.D.), Associate Professor, Doctoral Student of the Department of Theology and Religious Studies, National Pedagogical Dragomanov University; Kyiv, Ukraine; e-mail: a.kysliy@ukr.net; ORCID: https://orcid.org/0000-0001-8988-8242 


\title{
Modern ecumenism and the formation of the Christian social ideal
}

\begin{abstract}
It is determined the relevance and trends of studying in religious studies and theology problems of modern ecumenism. They are caused by a deepening interest in social and spiritual challenges and problems of the current world and urgency substantiation ways of their decision and development of theoretical ideas of formation ideal social system. The main line that pervades all modern ecumenism as a Christian movement aimed at renewing and uniting churches organic search for the most effective ways of forming Christian unity in the field of social issues. It is proved that the readiness of new and traditional Christian religious organizations for understanding and dialogue in this area are important for the sustainable development of social dominance. Millennial history of creation and testing the life of a person of Christian values and ideals is determined to be important argument in the construction of axiological priorities for the formation of modern and the future society. The real effectiveness and efficiency of ecumenism in the social field is confirmed by the rejection of the rigid controversy between Christian churches as unproductive for Christianity and the whole society. The reassessment of Christian churches and theologians are seen as motivated their own attitude to certain aspects of social life, there is a strengthening social service priorities. Experience in the struggle for social exclusion troubles and deepening of real inter-Christian and inter-religious dialogues interconnection demonstrate the prospect of forming common ground of the Christian social ideal. Maintaining one's religious identity and establishing directions formation of positive stable spiritual and moral coordinates of social changes lead to new inter-religious communication and reinforcement of those lasting elements the Christian social ideal that is possible now and in the future, reflecting the dynamic intensions of the present societal challenges.
\end{abstract}

Keywords: ideal, social ideal, Christian values, ecumenism, ecumenical movement, inter-Christian relations, inter-religious dialogue. 